\title{
PENGARUH MARKETING MIX (7P) DAN PERILAKU KONSUMEN TERHADAP KEPUTUSAN PEMBELIAN PRODUK HEALTHY FOOD BAR DI MALANG
}

\author{
Etty Caroline $^{1 *}$, Imam Santoso ${ }^{1}$, Panji Deoranto ${ }^{1}$ \\ ${ }^{1}$ Jurusan Teknologi Industri Pertanian, Fakultas Teknologi Pertanian \\ Universitas Brawijaya, Malang \\ * Penulis korespondensi; Email: ettycaroline@yahoo.com
}

\begin{abstract}
Abstrak: Peningkatan aktivitas dan pendapatan penduduk, mendorong diperlukannya makanan yang praktis, mudah, cepat cara penyajiannya serta bergizi. Healthy Food Bar (HFB) merupakan produk yang mempertimbangkan nilai gizi yang tinggi dan praktis. Tujuan penelitian ini untuk mengetahui pengaruh secara simultan dan parsial variabel dalam marketing mix (atribut produk, harga, saluran distribusi, promosi, orang, proses, lingkungan fisik) serta dalam perilaku konsumen (faktor lingkungan, individu, psikologis) terhadap keputusan pembelian HFB. Hasil penelitian dari 100 responden menunjukan variabel marketing mix (produk, harga, saluran distribusi, promosi, orang, proses, lingkungan fisik) dan perilaku konsumen (faktor lingkungan, individu, psikologis) secara simultan berpengaruh signifikan terhadap keputusan pembelian produk HFB. Secara parsial variabel marketing mix (produk, harga, saluran distribusi, promosi, orang, proses) dan variabel perilaku konsumen (faktor lingkungan, individu, psikologis) berpengaruh signifikan sedangkan variabel lingkungn fisik berpengaruh tidak signifikan terhadap keputusan pembelian produk HFB.
\end{abstract}

Kata kunci: HFB; marketing mix; perilaku konsumen; keputusan pembelian; regresi linier berganda.

Abstract: The improvement of activity and income the citizen need the practical, easy, fast, and nutritious foods. Healthy Food Bar (HFB) is a product that is considered a high nutritional value and practical. The purpose of this study was to determine the effect of variables simultaneously and partially in the marketing mix (product attributes, pricing, distribution channels, promotion, people, process, physical environment) as well as in consumer behavior (environmental factors, individual, psychological) to the purchasing decision HFB. The results of the study of 100 respondents showed variable marketing mix (product, price, distribution channels, promotion, people, process, physical environment) and consumer behavior (environmental factors, individual, psychological) simultaneously significant effect on product purchasing decisions HFB. In partial marketing mix (product, price, distribution channels, promotion, people, process) and consumer behavior variables (environmental factors, individual, psychological) significantly while the variable physical lingkungn insignificant effect on product purchasing decisions HFB.

Keywords: HFB; marketing mix; consumer behaviour; purchasing decision; multiple linear regression.

\section{PENDAHULUAN}

Peningkatan aktivitas dan pendapatan penduduk, mendorong semakin diperlukannya makanan dan minuman yang praktis, mudah, dan cepat cara penyajiannya serta bergizi tinggi. Pendapatan masyarakat yang cenderung meningkat secara bersamaan diikuti dengan perilaku hidup yang semakin modern, mengakibatkan permintaan yang tinggi terhadap bahan makanan dan minuman yang mudah diproses dan siap saji. Pemenuhan kalori dan protein lebih banyak dikonsumsi dari makanan dan minuman siap saji. Pemenuhan kalori dan protein lebih banyak dikonsumsi dari makanan dan minuman siap saji. Menurut BPS Republik Indonesia (2012), rata-rata konsumsi kalori dan protein penduduk (dalam gram) per kapita per hari untuk jenis makanan dan minuman jadi sebanyak 265,55 gram untuk kalori dan 7,93 gram untuk protein.

Menurut Lumiar (2010), Healthy Food Bar (HFB) merupakan produk yang bukan hanya sekedar camilan yang ditujukan untuk mengenyangkan, namun juga mempertimbangkan nilai gizi yang tinggi dan berguna untuk kesehatan. Makanan ini mengandung gula sehingga memberikan suplai energi, tahan lama (awet), siap makan, terbuat dari tepung-tepungan yang memiliki kandungan protein, karbohidrat, serta vitamin dan cocok dimakan untuk segala usia, dibentuk menjadi bentuk padat dan kompak ( a food bar form).

Dalam rangka memenuhi kebutuhan, keinginan dan kepuasan konsumen, para produsen saling bersaing untuk mengeluarkan atau menghasilkan produk-produk dengan menawarkan berbagai macam keunggulan dari masing-masing produk. Keputusan pembelian produk $H F B$ dipengaruhi oleh marketing mix yaitu product, price, place, promotion, people, physical evidence, dan proccess (7P) serta perilaku konsumen yaitu faktor lingkungan, faktor individu, dan faktor psikologis.

Tujuan penelitian ini untuk mengetahui pengaruh secara simultan dan parsial variabel-variabel dalam marketing mix yang terdiri atas atribut produk, harga 
$\left(\mathrm{x}_{1.2}\right)$, saluran distribusi $\left(\mathrm{x}_{1.3}\right)$, promosi $\left(\mathrm{x}_{1.4}\right)$, orang $\left(\mathrm{x}_{1.5}\right)$, proses $\left(\mathrm{x}_{1.6}\right)$, lingkungan fisik $\left(\mathrm{x}_{1.7}\right)$ serta variabelvariabel dalam perilaku konsumen yang terdiri atas faktor lingkungan $\left(\mathrm{x}_{2.1}\right)$, faktor individu $\left(\mathrm{x}_{2.2}\right)$, faktor psikologis $\left(\mathrm{x}_{2.3}\right)$ terhadap keputusan pembelian $H F B$. Penelitian dilakukan di Kota Malang sebagai studi kasus, sehingga hasil penelitian ini tidak dapat digunakan untuk menyimpulkan kondisi di wilayah lain.

\section{TINJAUAN TEORITIS}

Terdapat empat teori utama yang digunakan dalam penelitian ini yaitu Healthy Food Bar, marketing mix, perilaku konsumen dan analisis regresi linier berganda.

a. Healthy Food Bar

Food bar dibuat dari campuran bahan pangan (blended food) yang diperkaya dengan nutrisi yang kemudian dibentuk menjadi bentuk padat dan kompak (a food bar form). Food bar termasuk dalam jenis makanan ringan yang mudah untuk dikonsumsi. Di bidang industri makanan, food bar semakin banyak diproduksi secara komersial. Namun bagaimanapun juga tidak semua jenis food bar termasuk dalam makanan yang sehat dan layak untuk dikonsumsi. Maka dari itu dalam memilih jenis food bar haruslah berhati-hati dan diperhatikan komposisinya, terutama bagi beberapa orang yang melakukan diet khusus (Savige et al., 2007).

Menurur Leach (1995), nutrisi yang yang terkandung pada food bar antara lain serat, non protein hewani, karbohidrat sederhana, gula, antioksidan, dan lestitin yang menyediakan tambahan asam linoleat tak jenuh ganda, asam amino, magnesium, klorofil dan piridoksin, dan termasuk natrium dan kalium dalam rasio metabolisme yang menguntungkan, tidak mempunyai kolesterol, tanpa pengawet, tanpa perasa, dan jumlah minimum lemak jenuh. Beberapa food bar mengandung mengandung biji-bijian, kacang-kacangan, buah kering, pemanis dan bahan-bahan lainnya yang mungkin campuran dengan bahan pengikat, seperti sirup gula atau shortening, dan dibentuk menjadi bar dari ukuran yang diinginkan.

b. Marketing Mix

Menurut The Chartered Institute of Marketing (CIM) (2009), salah satu konsep utama strategi pemasaran modern adalah bauran pemasaran. Konsep tentang 4P (product, price, place dan promotion) yang dikenalkan oleh McDaniel et al. (2012) seiring dengan perkembangan bisnis mengalami modifikasi khususnya di bidang pemasaran. Menurut Lovelock dan Wright (1999) dalam pemasaran jasa, instrumen $4 \mathrm{P}$ berkembang menjadi 7P, dimana di dalamnya ditambahkan orang (people), proses (process) dan bukti fisik (physical evident). Bauran pemasaran merupakan kemampuan variabel yang terdiri dari $7 \mathrm{P}$ yaitu produk (product), harga (price), tempat (place), promosi (promotion), orang (people), proses (process), dan bukti fisik (physical evidence).

c. Perilaku Konsumen

Perilaku konsumen didefinisikan sebagai tindakan yang langsung terlibat dalam mendapatkan, mengkonsumsi, dan menghabiskan produk barang atau jasa termasuk proses keputusan yang mendahului dan mengikuti tindakan ini. Jadi perilaku konsumen pada hakekatnya adalah semua kegiatan, tindakan serta proses psikologis yang mendorong tindakan tersebut pada saat sebelum membeli, ketika membeli, menggunakan, menghabiskan produk. Perilaku konsumen dipengaruhi dan dibentuk oleh banyak faktor antara lain: pengaruh lingkungan, pengaruh individu, dan pengaruh psikologis (Engel et al, 1994).

d. Analisis Regresi Linier Berganda

Perhitungan regresi berganda bertujuan untuk memprediksi besarnya pengaruh variabel bebas terhadap variabel terikat, adapun rumusnya menurut Sugiyono (2003) sebagai berikut:

$\mathrm{Y}=\mathrm{a}+\mathrm{b}_{1} \mathrm{X}_{1}+\mathrm{b}_{2} \mathrm{X}_{2}+\ldots .+\mathrm{bnXn}+\mathrm{e}$

Keterangan:

$\mathrm{Y}=$ nilai hubungan variabel bebas terhadap variabel terikat

a = bilangan konstanta sebagai titik potong

b1, b2,..bn $=$ koefisien regresi ke $1,2, . .$, ke $n$

$\mathrm{X}_{1}, \mathrm{X}_{2}, . . \mathrm{Xn}=$ variabel bebas ke $1,2, \ldots$, , ke $\mathrm{n}$

$\mathrm{e}=$ erroritem

\section{PENGEMBANGAN HIPOTESIS}

Penelitian ini bersifat deskriptif analitik yang bertujuan untuk mengetahui pengaruh secara simultan dan parsial variabel-variabel terhadap keputusan pembelian $H F B$. Berdasarkan kerangka penelitian pada Gambar 1, maka hipotesis dalam penelitian ini adalah:

$\mathrm{H}_{1}$ : Marketing mix yang terdiri atas atribut produk $\left(\mathrm{x}_{1.1}\right)$, harga $\left(\mathrm{x}_{1.2}\right)$, saluran distribusi $\left(\mathrm{x}_{1.3}\right)$, promosi $\left(\mathrm{x}_{1.4}\right)$, orang $\left(\mathrm{x}_{1.5}\right)$, proses $\left(\mathrm{x}_{1.6}\right)$, lingkungan fisik $\left(\mathrm{x}_{1.7}\right)$ dan perilaku konsumen yang terdiri atas faktor lingkungan $\left(\mathrm{x}_{2.1}\right)$, faktor individu $\left(\mathrm{x}_{2.2}\right)$, faktor psikologis $\left(\mathrm{x}_{2.3}\right)$ mempengaruhi secara simultan keputusan pembelian produk $H F B(\mathrm{Y})$

$\mathrm{H}_{2}$ : Marketing mix yang terdiri atas atribut produk $\left(\mathrm{x}_{1.1}\right)$, harga $\left(\mathrm{x}_{1.2}\right)$, saluran distribusi $\left(\mathrm{x}_{1.3}\right)$, promosi $\left(\mathrm{x}_{1.4}\right)$, orang $\left(\mathrm{x}_{1.5}\right)$, proses $\left(\mathrm{x}_{1.6}\right)$, lingkungan fisik 
$\left(\mathrm{X}_{1.7}\right)$ dan perilaku konsumen yang terdiri atas faktor lingkungan $\left(\mathrm{x}_{2.1}\right)$, faktor individu $\left(\mathrm{x}_{2.2}\right)$, faktor psikologis $\left(\mathrm{x}_{2.3}\right)$ mempengaruhi secara parsial keputusan pembelian produk HFB (Y)

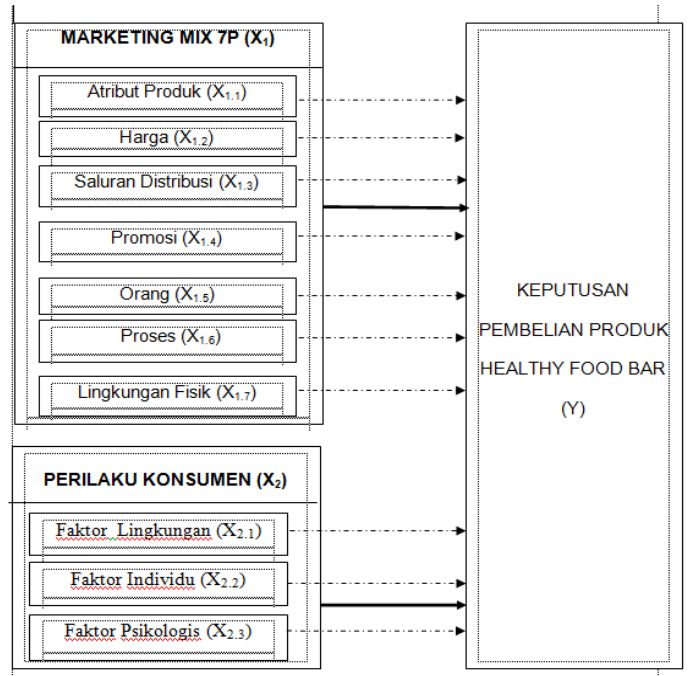

Keterangan:

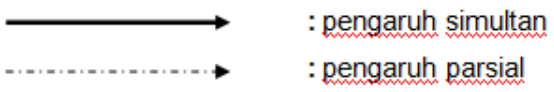

Gambar 1. Kerangka Penelitian

\section{METODE PENELITIAN}

Penelitian ini dilakukan di beberapa tempat yang menjual produk $H F B$ (HFB) serta tempat-tempat kebugaran seperti tempat senam, fitness dan sport center di kota Malang. Kota Malang dipilih sebagai tempat penelitian dengan pertimbangan bahwa kota ini merupakan kota yang cukup maju (kota terbesar kedua di Jawa Timur).

Teknik penarikan sampel yang digunakan dalam penelitian ini adalah teknik sampel tanpa peluang (non probability sampling), yaitu dengan metode judgement sampling. Kriteria-kriteria pengambilan sampel pada metode judgement sampling sebagai berikut:

1. Memilih konsumen yang bersedia diwawancarai atau mengisi kuisioner yang telah disediakan.

2. Konsumen menjadi responden adalah konsumen berjenis kelamin perempuan pada usia antara umur 18-40 tahun yang mengetahui, mengenal dan yang mengkonsumsi produk $H F B$

Alasan dipilihnya konsumen perempuan yang telah berusia diatas 18-40 tahun karena rata-rata dalam kehidupannya perempuan lebih menyukai makanan/ camilan seperti $H F B$ karena memperhatikan penampilan dan peduli terhadap kesehatan/badannya. Jumlah responden yang akan ditentukan dalam penelitian ini adalah 100 orang. Teknik pengumpulan data yang akan dipakai dalam penelitian ini adalah:
1. Kuesioner

Kuesioner yang diberikan kepada responden bersifat tertutup, dimana responden hanya memilih alternatif jawaban yang tersedia pada kuesioner.

2. Teknik wawancara

Wawancara ini dilakukan untuk memperoleh data pendukung atau penunjang dari kuesioner.

3. Studi Pustaka

Instrumen pengukuran variabel yang digunakan dalam penelitian ini adalah skala Likert, untuk mengukur sikap, pendapat dan persepsi seseorang atau sekelompok tentang kejadian atau gejala sosial (Singarimbun dan Effendi, 2006). Pada penelitian ini, bobotnya adalah 1 sampai 5. Pilihan jawaban:
a) Sangat setuju (SS) nilai 5
b) Setuju (S)
nilai 4
c) Netral
d) Tidak Setuju (TS)
nilai 3
e) Sangat tidak setuju (STS)
nilai 2

Perhitungan dalam penelitian ini menggunakan program komputer Statistical Product and Service Solution (SPSS) untuk Windows 7 untuk menganalisis uji validitas, uji reliabilitas, analisis regresi linier berganda, uji normalitas, uji multikolinieritas, uji heteroskedastisitas, uji t dan uji F. Variabel dan indikator penelitian untuk setiap variabel marketing mix, perilaku konsumen dan keputusan pembelian konsumen dapat dilihat pada Tabel 1 dibawah ini.

Tabel 1. Variabel dan Indikator Penelitian

\begin{tabular}{l|l|c|}
\hline Variabel & Indikator & Notasi \\
\hline MarketingMix $\left(X_{1}\right)$ & Atribut Produk & $\mathrm{X}_{1.1}$ \\
& Harga & $\mathrm{X}_{1.2}$ \\
& Saluran Distribusi & $\mathrm{X}_{1.5}$ \\
& Promosi & $\mathrm{X}_{1.4}$ \\
& Orang & $\mathrm{X}_{1.5}$ \\
& Proses & $\mathrm{X}_{1.6}$ \\
& Lingkungan Fisik & $\mathrm{X}_{1.7}$ \\
Perilaku Konsumen $\left(X_{2}\right)$ & Faktor Lingkungan & $\mathrm{X}_{2.1}$ \\
& Faktor Individu & $\mathrm{X}_{2.2}$ \\
& Faktor Psikologis & $\mathrm{X}_{2.5}$ \\
Keputusan membeli $(\mathrm{Y})$ & Keputusan aktual pembelian & $\mathrm{Y}_{1.1}$ \\
& Frekuensi pembelian & $\mathrm{Y}_{1.2}$ \\
& Rekomendasi & $\mathrm{Y}_{1.3}$ \\
& Royalitas & $\mathrm{Y}_{1.4}$ \\
\hline
\end{tabular}

\section{HASIL DAN PEMBAHASAN}

\section{Karakteristik Responden}

Karakteristik responden menggambarkan keadaan responden pada penelitian ini, yang meliputi usia, pendidikan terakhir, pekerjaan, penghasilan per bulan (Rp), status responden, jumlah anggota keluarga. Responden yang diambil pada penelitian adalah konsumen berjenis kelamin perempuan yang telah berusia diatas 18-40 tahun sebanyak 100 orang. 
Tabel 2. Karakteristik Umum Responden

\begin{tabular}{|c|c|c|c|}
\hline \multirow{2}{*}{ No. } & \multirow{2}{*}{ Profil Responden } & \multicolumn{2}{|r|}{ Jumlah } \\
\hline & & Orang & Persentase (\%) \\
\hline \multirow[t]{5}{*}{1.} & Usia: 18-20tabun & 57 & \\
\hline & $\begin{array}{l}\text { a. 18-20tanun } \\
\text { b. 21-25 tahun }\end{array}$ & 22 & 22 \\
\hline & c. 26-30 tahun & 17 & 17 \\
\hline & d. $31-35$ tahun & 2 & \\
\hline & $\begin{array}{l}\text { e. } 36-40 \text { tahun } \\
\text { Pendidikan Terakhir }\end{array}$ & 2 & \\
\hline \multirow{5}{*}{2.} & 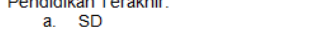 & 4 & \\
\hline & b. SMP & 4 & 4 \\
\hline & c. SLTA & 43 & \\
\hline & d. Diploma & $\begin{array}{r}9 \\
35\end{array}$ & 9 \\
\hline & $\begin{array}{l}\text { e. Sarjana } \\
\text { f. Pascasarjana }\end{array}$ & $\begin{array}{r}50 \\
5\end{array}$ & \\
\hline \multirow[t]{5}{*}{3.} & Pekerjaan: & & \\
\hline & a. Pelajar / Mahasiswa & 53 & \\
\hline & $\begin{array}{l}\text { b. Wiraswasta } \\
\text { c. PNS }\end{array}$ & 11 & 11 \\
\hline & d. Ibu Rumah Tangga & $\begin{array}{r}4 \\
15\end{array}$ & $\begin{array}{r}4 \\
15\end{array}$ \\
\hline & e. Karyawan Swasta & $\begin{array}{l}15 \\
11\end{array}$ & 11 \\
\hline \multirow[t]{6}{*}{4.} & Pendapatan/uang saku perbulan: & & \\
\hline & a. $<\operatorname{Rp} 500.000$ & & 27 \\
\hline & b. Rp $500.000-$ Rp 1.000 .000 & 24 & 24 \\
\hline & c. Rp $1.000 .001-<\operatorname{Rp} 2.500 .000$ & 34 & 34 \\
\hline & d. Rp $2.500 .000-<$ Rp 5.000 .000 & 15 & 15 \\
\hline & e. $>$ Rp 5.000 .000 & 0 & 0 \\
\hline \multirow[t]{2}{*}{5.} & Status: & & \\
\hline & $\begin{array}{ll}\text { a. Menikah } \\
\text { b. Belum Menikah }\end{array}$ & $\begin{array}{l}28 \\
72\end{array}$ & 28 \\
\hline \multirow[t]{3}{*}{6} & Jumlah Anggota Keluarga: & & \\
\hline & $\begin{array}{cc}\text { a. } & 2-3 \text { orang } \\
\text { b. } & 4-5 \text { orang }\end{array}$ & $\begin{array}{l}30 \\
56\end{array}$ & $\begin{array}{l}30 \\
56\end{array}$ \\
\hline & c. $6-8$ orang & 14 & 14 \\
\hline
\end{tabular}

Responden berjenis kelamin perempuan dipilih karena perempuan cenderung memiliki sifat lebih perhatian terhadap penampilan dan kesehatan/badannya (Manongko, 2011).

Berdasarkan Tabel 2, responden yang lebih banyak mengkonsumsi produk Healthy Food Bar responden dengan kelompok usia 18-20 tahun sebanyak 57 orang atau $57 \%$ dari jumlah keseluruhan responden. Hal ini menunjukkan bahwa produk HFB memiliki segmen pembeli yang berusia 18-20 tahun. Rentang usia tersebut tergolong usia muda dan produktif. Pada usia tersebut responden banyak bekerja dan bersosialisasi dengan teman sebaya dan berinteraksi dengan berbagai media, sehingga cukup mudah untuk menerima dan memahami isu-isu lingkungan (Peter,2000).

Responden yang berlatar belakang pelajar/mahasiswa merupakan kelompok yang paling banyak mengkonsumsi produk HFB yakni sebanyak 53 orang atau $53 \%$ dari total responden. Hampir sama dengan rentang usia. Pelajar/mahasiswa juga termasuk kelompok muda dan produktif yang banyak berinteraksi dengan teman sebaya dan media. Responden yang paling banyak mengkonsumsi produk HFB adalah kelompok yang berpendidikan terakhir SMA (Sekolah Menengah Atas) yaitu sebanyak 43 orang atau $43 \%$ dari total keseluruhan responden.

Kelompok dengan tingkat pendapatan antara Rp 1.000.001 - Rp 2.499.000 merupakan kelompok yang mendominasi daripada kelompok pendapatan yang lain yaitu sebanyak 34 orang atau $34 \%$ dari total keseluruhan responden. Harga produk yang berkisar antara Rp 2.950 - Rp. 5000 dirasa cukup terjangkau pada kelompok pendapatan ini. Selain itu, sebanyak 72 responden yang mengkonsumsi produk HFB berstatus belum menikah. Status perkawinan juga berpengaruh terhadap tingkat konsumsi.

\section{Distribusi Frekuensi Jawaban Item Pernyataan}

\section{a. Marketing Mix}

Produk ( $\left.\mathbf{X}_{1.1}\right)$

Tabel 3. Tanggapan Responden Terhadap Variabel Produk

\begin{tabular}{|c|c|c|c|c|c|c|}
\hline \multirow{2}{*}{ ITEM } & 1 & 2 & 3 & 4 & 5 & \multirow{2}{*}{ MEAN } \\
\hline & $\%$ & $\%$ & $\%$ & $\%$ & $\%$ & \\
\hline Rasa khas dan engk $\left(X_{1.1 .1}\right)$ & 2 & 22 & 30 & 33 & 13 & 3,3 \\
\hline Zst bermanfast $\left(X_{1.1 .2}\right)$ & 0 & 2 & 21 & 54 & 22 & 4 \\
\hline Mudgh dikonsumsi $\left(X_{1.1 .3}\right)$ & 0 & 7 & 12 & 43 & 38 & 4,1 \\
\hline Segel kemasan baik $\left(X_{1.1 .4}\right)$ & 0 & 0 & 14 & 56 & 30 & 4,2 \\
\hline |zin halgl dgri Depkes $\left(X_{1.1 .5}\right)$ & 0 & 0 & 11 & 59 & 30 & 4,2 \\
\hline Desgin kemasan menarik $\left(X_{1.1 .8}\right)$ & 0 & 1 & 20 & 51 & 28 & 4,1 \\
\hline & & & & & & 3,98 \\
\hline
\end{tabular}

Secara keseluruhan berdasarkan akumulasi tanggapan responden tentang variabel produk diperoleh rata-rata sebesar 3,98. Hasil tabulasi jawaban koresponden diketahui bahwa sebanyak $33 \%$ responden setuju bahwa produk HFB mempunyai rasa yang khas dan enak. Sebanyak 54\% responden setuju bahwa produk HFB memiliki sejumlah zat bermanfaat yang baik untuk kesehatan. $43 \%$ responden juga setuju bahwa produk HFB mudah untuk dikonsumsi dan $56 \%$ responden menyatakan sangat setuju bahwa segel kemasan dari produk HFB dalam keadaan baik. Sebanyak $59 \%$ responden setuju bahwa produk HFB mempunyai izin halal. $51 \%$ responden menyatakan setuju bahwa produk mempunyai desain kemasan yang menarik.

\section{Harga $\left(\mathbf{X}_{1.2}\right)$}

Tabel 4. Tanggapan Responden Terhadap Variabel Harga

\begin{tabular}{|c|c|c|c|c|c|c|}
\hline \multirow{2}{*}{ ITEM } & 1 & 2 & 3 & 4 & 5 & \multirow{2}{*}{ MEAN } \\
\hline & $\%$ & $\%$ & $\%$ & $\%$ & $\%$ & \\
\hline Harga terjangkau $\left(X_{12,1}\right)$ & 4 & 23 & 36 & 27 & 10 & 3,2 \\
\hline $\begin{array}{l}\text { Harga sesuai harapan } \\
\left.X_{1} 12 \mathrm{~s}\right)\end{array}$ & 8 & 36 & 30 & 21 & 5 & 2,8 \\
\hline $\begin{array}{l}\text { Harga terjangkgu } \\
\text { menyebabksn pembelian } \\
\text { teratur }\left(X_{123}\right)\end{array}$ & 17 & 36 & 38 & 5 & 4 & 2,4 \\
\hline & & & & & & 2,8 \\
\hline
\end{tabular}

Dari akumulasi tanggapan responden tentang variabel produk diperoleh rata-rata sebesar 2,8. Hal ini mencerminkan bahwa produk HFB dinilai netral oleh responden. Sebanyak $36 \%$ responden menyatakan netral bahwa harga produk HFB saat ini sudah rasional dan sesuai dengan manfaat yang diperoleh dan sebanyak $36 \%$ responden ti dak setuju bahwa harga sesuai dengan harapan konsumen. Harga merupakan salah satu penentu keberhasilan perusahaan karena harga menentukan seberapa besar keuntungan yang akan diperoleh dari penjualan produknya. Menetapkan harga terlalu tinggi akan menyebabkan penjualan akan menurun. Sebanyak 38\% responden menyatakan netral bahwa harga yang terjangkau menyebabkan pembelian teratur. 


\section{Saluran Distribusi ( $\left.\mathbf{X}_{1.3}\right)$}

Tabel 5. Tanggapan Responden Terhadap Variabel Saluran Distribusi

\begin{tabular}{|c|c|c|c|c|c|c|}
\hline \multirow{2}{*}{ ITEM } & 1 & 2 & 3 & 4 & 5 & \multirow{2}{*}{ MEAN } \\
\hline & $\%$ & $\%$ & $\%$ & $\%$ & $\%$ & \\
\hline $\begin{array}{l}\text { Jaminan ketersediaan di } \\
\text { foko-toko, supermarket, dan } \\
\text { fempat kebugaran }\left(\mathrm{X}_{1.31}\right)\end{array}$ & 2 & 18 & 29 & 40 & 11 & 3,4 \\
\hline $\begin{array}{l}\text { Lokasi penjualanterjangkau } \\
\left(X_{1,32}\right)\end{array}$ & 2 & 21 & 24 & 39 & 14 & 3,4 \\
\hline $\begin{array}{l}\text { Di setiap toko produk } \\
\text { lersedia lengkap }\left(\mathrm{X}_{1,3.3}\right)\end{array}$ & 6 & 27 & 40 & 22 & 5 & 2,9 \\
\hline & & & & & & 3,23 \\
\hline
\end{tabular}

Akumulasi tanggapan responden tentang variabel saluran distribusi diperoleh rata-rata sebesar 3,23 mencerminkan bahwa konsumen produk HFB memiliki tanggapan netral. Dari jawaban responden juga dapat diketahui bahwa sebanyak $40 \%$ responden menyatakan bahwa ada jaminan ketersediaan produk HFB di toko-toko, supermarket, dan tempat kebugaran. Sebanyak 39\% responden setuju bahwa tempat penjualan produk mudah dijangkau sehingga mudah untuk mendapatkan produk dan sebanyak $42 \%$ responden netral bahwa di setiap toko tersedia lengkap varian rasa dan jenis dari produk HFB.

\section{$\operatorname{Promosi}\left(\mathbf{X}_{1.4}\right)$}

Akumulasi tanggapan responden tentang variabel promosi diperoleh rata-rata sebesar 3,98. Responden menyatakan setuju (59\%) bahwa produk HFB dipromosikan melalui berbagai media cetak dan elektronik. Responden juga menyatakan setuju (44\%) produk HFB memberikan informasi tentang produk secara lengkap. Informasi produk antara lain komposisi, informasi nilai gizi, berat bersih, kode produksi, expired, dll. Sebanyak 39,38\% responden juga setuju bahwa dalam promosinya produk HFB menyampaikan pesan peduli akan kesehatan. Tanggapan responden ditampilkan pada Tabel 6 dibawah ini.

Tabel 6. Tanggapan Responden Terhadap Variabel Promosi

\begin{tabular}{|c|c|c|c|c|c|c|}
\hline \multirow{2}{*}{ ITEM } & 1 & 2 & 3 & 4 & 5 & \multirow{2}{*}{ MEAN } \\
\hline & $\%$ & $\%$ & $\%$ & $\%$ & $\%$ & \\
\hline $\begin{array}{l}\text { Promosi melalui berbagai } \\
\text { media cetak dan elektronik } \\
\left(\mathrm{X}_{1,41}\right)\end{array}$ & 0 & 2 & 18 & 59 & 21 & 4 \\
\hline $\begin{array}{l}\text { Memberikan informasi tentang } \\
\text { produksecara lengkap }\left(X_{1.122}\right)\end{array}$ & 0 & 11 & 33 & 44 & 12 & 3,6 \\
\hline $\begin{array}{l}\text { Menyampaikan pesan peduli } \\
\text { akan kesehatan }\left(X_{1.43}\right)\end{array}$ & 1 & 3 & 25 & 50 & 21 & 3,9 \\
\hline & & & & & & 3,83 \\
\hline
\end{tabular}

\section{Orang $\left(\mathbf{X}_{1.5}\right)$}

Tabel 7. Tanggapan Responden Terhadap Variabel Orang

\begin{tabular}{|l|c|c|c|c|c|c|}
\hline \multirow{2}{*}{ ITEM } & 1 & 2 & 3 & 4 & 5 & \multirow{2}{*}{ MEAN } \\
\cline { 2 - 6 } & $\%$ & $\%$ & $\%$ & $\%$ & $\%$ & \\
\hline $\begin{array}{l}\text { Pelayanan pramuniagayang } \\
\text { ramah dan bersedia membantu } \\
\left(X_{1,51)}\right)\end{array}$ & 2 & 7 & 60 & 22 & 9 & 3,3 \\
\hline $\begin{array}{l}\text { Mempunyai pelayananuntuk } \\
\text { pelanggan (Customer Service) } \\
\left(X_{1,52}\right)\end{array}$ & 0 & 10 & 51 & 33 & 6 & 3,4 \\
\hline & Sumber: Data yang diolah (2013) & & & & 3,35 \\
\hline
\end{tabular}

\section{Orang $\left(\mathbf{X}_{15}\right)$ dan Proses $\left(\mathbf{X}_{1.6}\right)$}

Tabel 8. Tanggapan Responden Terhadap Variabel Orang dan Proses

\begin{tabular}{|l|c|c|c|c|c|c|}
\hline \multirow{2}{*}{ ITEM } & 1 & 2 & 3 & 4 & 5 & \multirow{2}{*}{ MEAN } \\
\cline { 2 - 7 } & $\%$ & $\%$ & $\%$ & $\%$ & $\%$ & \\
\hline $\begin{array}{l}\text { Pelayanan keluhan pelanggann } \\
\text { yang cepatdan baik }\left(X_{1.53}\right)\end{array}$ & 1 & 9 & 71 & 14 & 5 & 3,1 \\
\hline $\begin{array}{l}\text { Proses pelayanan } \\
\text { pembayaran cepat }\left(X_{1.5 .}\right)\end{array}$ & 1 & 5 & 67 & 21 & 6 & 3,3 \\
\hline
\end{tabular}

Tanggapan responden tentang variabel promosi diperoleh rata-rata sebesar 3,35. Sebanyak 60\% responden menyatakan netral terhadap pelayanan pramuniaga yang ramah dan bersedia membantu. Sebanyak 51\% responden menyatakan netral bahwa produk HFB mempunyai pelayanan untuk pelanggan (Customer Service). Excellent Customer Service adalah memberikan pelayangan lebih dari apa yang diharapkan pelanggan (Haryadi, 2009). Sebanyak 67\% responden juga menyatakan netral terhadap proses pelayanan pembayaran produk HFB cepat.

Berdasarkan akumulasi tanggapan responden tentang variabel proses diperoleh rata-rata sebesar 3,2. Responden sebanyak $71 \%$ menyatakan netral terhadap pelayanan keluhan pelanggan cepat dan baik. Sebanyak 67\% juga menyatakan netral terhadap proses pelayanan pembayaran yang cepat. Dengan proses pembayaran yang cepat dan mudah meningkatkan kepuasan konsumen sehingga dapat menyebabkan pembelian yang teratur.

\section{Lingkungan Fisik $\left(\mathbf{X}_{1.7}\right)$}

Tabel 8. Tanggapan Responden Terhadap Variabel Lingkungan Fisik

\begin{tabular}{|c|c|c|c|c|c|c|}
\hline \multirow{2}{*}{ ITEM } & 1 & 2 & 3 & 4 & 5 & \multirow{2}{*}{ MEAN } \\
\hline & $\%$ & $\%$ & $\%$ & $\%$ & $\%$ & \\
\hline $\begin{array}{l}\text { Penataan counter boxyang } \\
\text { menarik disesuaikan dengan } \\
\text { rasa }\left(X_{1.6 .1}\right)\end{array}$ & 2 & 7 & 27 & 51 & 13 & 3,7 \\
\hline $\begin{array}{l}\text { Kondisitempat pembelianyang } \\
\text { bersih, rapi dan nyaman }\left(X_{1.62}\right)\end{array}$ & 0 & 2 & 28 & 54 & 16 & 3,8 \\
\hline & & & & & & 3,75 \\
\hline
\end{tabular}

Dari Tabel di atas akumulasi tanggapan responden tentang variabel lingkungan fisik diperoleh ratarata sebesar 3,75. Responden menyatakan setuju (51\%) bahwa produk mempunyai penataan counter box yang menarik disesuaikan dengan rasa. Salah satu daya tarik pada toko adalah penataan barang dagangannya. 54\% responden juga menyatakan setuju terhadap kondisi tempat pembelian Produk HFB yang bersih, rapi, dan nyaman. 


\section{b. Perilaku Konsumen}

\section{Faktor Lingkungan $\left(\mathbf{X}_{2.1}\right)$}

Tabel 9. Tanggapan Responden Terhadap Faktor Lingkungan

\begin{tabular}{|c|c|c|c|c|c|c|}
\hline \multirow{2}{*}{ ITEM } & 1 & 2 & 3 & 4 & 5 & \multirow{2}{*}{ MEAN } \\
\hline & $\%$ & $\%$ & $\%$ & $\%$ & $\%$ & \\
\hline $\begin{array}{l}\text { Kemampuan daya beli } \\
\text { produk yang tinggi }\left(X_{2.11}\right)\end{array}$ & 9 & 21 & 45 & 22 & 3 & 2,9 \\
\hline $\begin{array}{l}\text { Menunjukkan kelas sosial di } \\
\text { masyarakat }\left(X_{21.2}\right)\end{array}$ & 30 & 42 & 20 & 8 & 0 & 2,1 \\
\hline $\begin{array}{l}\text { Pengaruh dari keluarga } \\
\left(X_{21.3}\right)\end{array}$ & 21 & 45 & 23 & 9 & 2 & 2,3 \\
\hline $\begin{array}{l}\text { Situasi pembelian yang } \\
\text { nyaman mempengaruhi } \\
\text { konsumen dalam membeli } \\
\text { Produk }\left(\mathrm{X}_{21.4}\right)\end{array}$ & 5 & 23 & 42 & 26 & 4 & 3 \\
\hline & & & & & & 2,57 \\
\hline
\end{tabular}

Hasil analisis keempat butir pernyataan pada variabel faktor lingkungan diperoleh skor rerata jawaban responden adalah 2,57 artinya responden cenderung netral. Sebanyak 45\% responden menyatakan netral terhadap kemampuan daya beli yang tinggi. Responden juga menyatakan tidak setuju (42\%) bahwa membeli produk HFB karena ingin menunjukkan kelas sosial di masyrakat. Sebanyak $45 \%$ responden tidak setuju bahwa minat membeli konsumen ditentukan oleh adanya pengaruh dari keluarga mengenai produk. Sebanyak $42 \%$ responden menyatakan netral terhadap situasi pembelian yang nyaman mempengaruhi konsumen dalam membeli produk.

\section{Faktor Individu ( $\left.\mathbf{X}_{2.2}\right)$}

Tabel 10. Tanggapan Responden Terhadap Faktor Individu

\begin{tabular}{|c|c|c|c|c|c|c|}
\hline ITEM & 1 & 2 & 3 & 4 & 5 & MEAN \\
\hline $\begin{array}{l}\text { Konsumenmembeli Produk } \\
\text { sesuai dengan } \\
\text { penghasilaripendapatan } \\
x_{2} \text {. }\end{array}$ & 15 & 21 & 40 & 24 & 0 & 2,7 \\
\hline 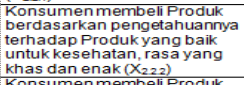 & 3 & 11 & 26 & 47 & 13 & 3,6 \\
\hline $\begin{array}{l}\text { Konsumen membeleli r roduk } \\
\text { karena mengikuti trend } \\
\text { makanan saat ini }\left(x_{223}\right)\end{array}$ & 14 & 39 & 30 & 16 & 1 & 2,5 \\
\hline $\begin{array}{l}\text { Konsumenmembeli Produk } \\
\text { karena sesuai dengan gaya } \\
\text { hidup }\left(X_{222}\right)\end{array}$ & 15 & 42 & 31 & 10 & 2 & 2,4 \\
\hline $\begin{array}{l}\text { Konsumenmembell Produk } \\
\text { karena cita rasayang sesuai } \\
\left.\text { dengan selera ( } \chi_{225}\right)\end{array}$ & 10 & 15 & 37 & 34 & 4 & 3,1 \\
\hline
\end{tabular}

Butir pernyataan pada variabel faktor individu diperoleh skor rerata jawaban responden adalah 2,86 artinya jawaban responden umumnya cenderung netral. Konsumen juga berpendapat netral $(40 \%)$ bahwa pembelian produk sesuai dengan penghasilan/ pendapatan. Hampir setengah dari responden yaitu sebanyak $47 \%$ setuju bahwa keputusannya membeli produk berdasarkan pengetahuannya terhadap produk yang baik untuk kesehatan, rasa yang khas dan enak.

Responden menyatakan tidak setuju (39\%) apabila keputusannya membeli produk HFB karena mengikuti trend makanan saat ini. Responden juga menyatakan tidak setuju (42\%) apabila membeli produk karena sesuai dengan gaya hidup. Responden berpendapat netral (37\%) bahwa keputusannya membeli produk karena cita rasa yang sesuai dengan selera.

\section{Faktor Psikologi $\left(\mathbf{X}_{2.3}\right)$}

Tabel 11. Tanggapan Responden erhadap Faktor Psikologi

\begin{tabular}{|l|c|c|c|c|c|c|}
\hline \multicolumn{1}{|c|}{ ITEM } & $\mathbf{1}$ & $\mathbf{2}$ & $\mathbf{3}$ & $\mathbf{4}$ & $\mathbf{5}$ & MEAN \\
\cline { 2 - 6 } & $\%$ & $\%$ & $\%$ & $\%$ & $\%$ & \\
\hline $\begin{array}{l}\text { Konsumenmembeli Produk } \\
\text { karena memiliki penerimaan } \\
\text { sebuah informasi yang baik } \\
\left(\mathrm{X}_{23.1}\right)\end{array}$ & 4 & 9 & 35 & 47 & 5 & 3,4 \\
$\begin{array}{l}\text { Konsumen membeli Produk } \\
\text { karena memiliki pengalaman } \\
\text { yang baik dalam } \\
\text { mengkonsumsi Produk } \\
\left(\mathrm{X}_{232}\right)\end{array}$ & 8 & 14 & 42 & 32 & 4 & 3,1 \\
$\begin{array}{l}\text { Konsumenmembeli Produk } \\
\text { karena adanya perubahan } \\
\text { sikap dan perilaku dalam } \\
\text { mengkonsumsi makanan } \\
\left(\mathrm{X}_{233}\right)\end{array}$ & 11 & 29 & 40 & 18 & 2 & 2,7 \\
\hline \\
\hline
\end{tabular}

Dari tabel diatas butir pernyataan pada variabel faktor psikologi diperoleh skor rerata jawaban responden adalah 3,06. Responden menyatakan netral (35\%) bahwa konsumen membeli produk karena memiliki penerimaan sebuah informasi yang baik. Sebanyak $42 \%$ responden juga netral bahwa dalam membeli produk karena memiliki pengalaman yang baik dalam mengkonsumsi produk HFB. Sebanyak $40 \%$ responden netral bahwa dalam mengkonsumsi produk dipengaruhi adanya perubahan sikap dan perilaku konsumen dalam mengkonsumsi makanan. Sikap dan perilaku konsumen dapat dipengaruhi secara persuasif melalui komunikasi (Engel et al,1994).

\section{c. Keputusan Pembelian (Y)}

Tabel 12. Tanggapan Responden Terhadap Keputusan Pembelian

\begin{tabular}{|c|c|c|c|c|c|c|}
\hline \multirow{2}{*}{ ITEM } & 1 & 2 & 3 & 4 & 5 & \multirow{2}{*}{ MEAN } \\
\hline & $\%$ & $\%$ & $\%$ & $\%$ & $\%$ & \\
\hline $\begin{array}{l}\text { Konsumenmembeli } \\
\text { Produk karena } \\
\text { pertimbangan kesehatan } \\
\text { dan lingkungan }\left(\gamma_{1.1 .1}\right)\end{array}$ & 5 & 11 & 36 & 40 & 8 & 3,4 \\
\hline $\begin{array}{l}\text { Konsumensering membeli } \\
\text { Produk }\left(\gamma_{1,21}\right)\end{array}$ & 16 & 26 & 43 & 14 & 1 & 2,6 \\
\hline $\begin{array}{l}\text { Konsumen bersedia } \\
\text { merekomendasikan } \\
\text { Produk kepada keluarga } \\
\text { dan teman }\left(\gamma_{1.3 .1}\right)\end{array}$ & 7 & 11 & 57 & 21 & 4 & 3 \\
\hline $\begin{array}{l}\text { Konsumen bersedia } \\
\text { menjadipelanggansetia } \\
\text { pembeliProduk }\left(Y_{1.41}\right)\end{array}$ & 13 & 14 & 57 & 15 & 1 & 2,8 \\
\hline & & & & & & 2,95 \\
\hline
\end{tabular}

Hasil analisis jawaban responden terhadap keempat butir pernyataan pada variabel keputusan pembeliaan produk HFB diperoleh skor rerata adalah 2,95 artinya ada kecendurungan responden netral. Sebanyak $40 \%$ responden menyatakan setuju atas kesediaannya membeli Produk HFB karena pertimbangan kesehatan dan lingkungan. Konsumen yang 
sadar bahwa produk yang dikonsumsinya dapat memberikan manfaat kesehatan dan lingkungan merupakan wujud hidup sehat. Sebanyak $43 \%$ responden juga cukup setuju (netral) bahwa mereka cukup sering membeli produk. Hampir setengah lebih dari responden yaitu sebanyak $57 \%$ netral untuk bersedia merekomendasikan produk kepada keluarga dan teman serta bersedia untuk menjadi pelanggan setia pembeli produk $H F B$.

\section{Pengolahan Data dengan Regresi Linier Berganda}

a. Asumsi Normalitas (Plot Uji Normalitas)

Grafik histogram pada variabel marketing mix menunjukkan pola yang mendekati bentuk bel dan plot linear. Dapat disimpulkan bahwa data berdistribusi normal dan memenuhi asumsi normalitas.

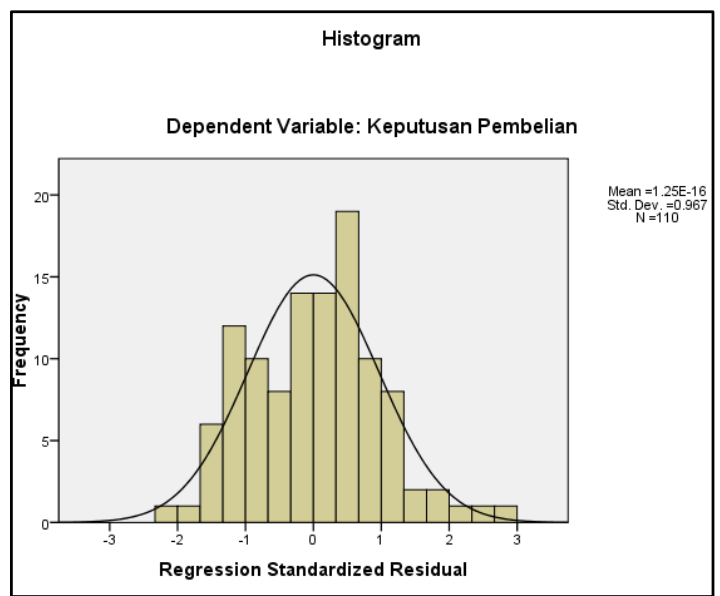

Gambar 2. Histogram Pada Variabel Marketing Mix

Grafik histogram pada variabel perilaku konsumen menunjukkan pola yang sama.

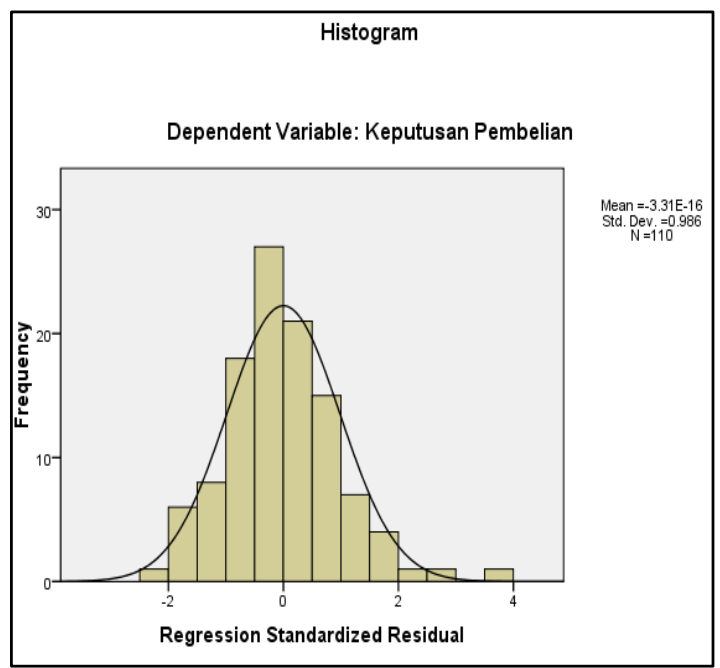

Gambar 3. Histogram Pada Variabel Perilaku Konsumen b. Asumsi Multikolinieritas

Berdasarkan hasil pengujian non multikolinieritas dengan menggunakan Variance Inflation Factor (VIF) pada variabel marketing mix didapatkan nilai VIF pada atribut produk $(2,612)$, harga $(1,468)$, saluran distribusi $(2,095)$, promosi $(2,786)$, orang $(2,855)$, proses $(2,916)$, dan lingkungan fisik $(1,815)$ lebih kecil dari 10 , maka hipotesis $\mathrm{H}_{0}$ ditolak yaitu tidak terdapat hubungan linier variabel antar variabel bebas pada variabel marketing mix. Dari hasil pengujian non multikolinieritas dengan menggunakan Variance Inflation Factor (VIF) pada variabel perilaku konsumen didapat nilai VIF pada faktor lingkungan $(1,931)$, faktor individu $(4,238)$, dan faktor psikologis $(3,164)$ lebih kecil dari 10, maka hipotesis $\mathrm{H}_{0}$ ditolak yang berarti tidak terdapat hubungan linier variabelantar variabel bebas pada model kedua.

c. Asumsi Non Heterokedastisitas

Dari gambar plot uji non heterokedastisitas variabel marketing mix terlihat titik-titik menyebar secara acak dan tidak membentuk suatu pola tertentu, maka hipotesis $\mathrm{H}_{0}$ ditolak dan regresi memenuhi asumsi non heterokedastis.

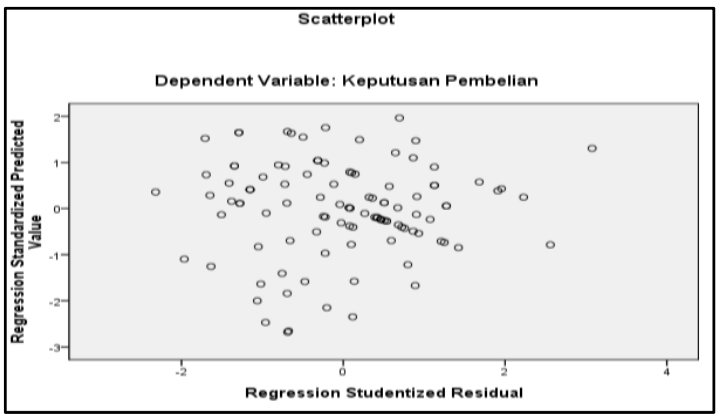

Gambar 4. Plot Uji Non Heterokedastisitas Variabel Marketing Mix

Pada gambar gambar plot non heterokedastisitas variabel perilaku konsumen terlihat titik-titik menyebar secara acak dan tidak membentuk suatu pola tertentu, maka hipotesis $\mathrm{H}_{0}$ ditolak dan pada variabel perilaku konsumen regresi memenuhi asumsi non heterokedastisitas dan layak dipakai.

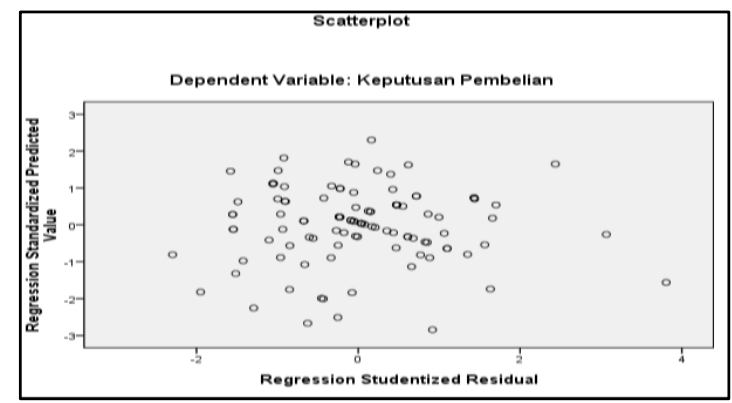

Gambar 5. Plot Uji Non Heterokedastisitas Variabel Perilaku Konsumen 
d. Pengujian Hipotesis Simultan

Nilai $F_{\text {hitung }}$ pada variabel marketing mix sebesar 36,183 dan nilai signifikansi sebesar 0,000. Karena nilai $\mathrm{F}_{\text {hitung }}$ lebih besar dari nilai $\mathrm{F}_{\text {tabel }}(36,183$ > $2,101)$ atau nilai signifikansi lebih kecil dari alpha $5 \%(0,000<0,050)$, maka hipotesis $\mathrm{H}_{0}$ ditolak dan dapat disimpulkan bahwa secara bersama-sama terdapat pengaruh yang nyata dari variabel atribut produk $\left(\mathrm{X}_{1.1}\right)$, harga $\left(\mathrm{X}_{1.2}\right)$, saluran distribusi $\left(\mathrm{X}_{1.3}\right)$, promosi $\left(\mathrm{X}_{1.4}\right)$, orang $\left(\mathrm{X}_{1.5}\right)$, proses $\left(\mathrm{X}_{1.6}\right)$, dan lingkungan fisik $\left(X_{1.7}\right)$ terhadap variabel keputusan pembelian (Y) dengan tingkat batas kesalahan 5\%. Nilai $F_{\text {hitung }}$ pada variabel Perilaku Konsumen sebesar 86,835 dan nilai signifikansi sebesar 0,000. Karena nilai $F_{\text {hitung }}$ lebih besar dari nilai $F_{\text {tabel }}$ $(86,835>2,690)$ atau nilai signifikansi lebih kecil dari alpha $5 \%(0,000<0,050)$, maka hipotesis $\mathrm{H}_{0}$ ditolak dan dapat disimpulkan bahwa secara bersama-sama terdapat pengaruh yang nyata dari variabel faktor lingkungan $\left(\mathrm{X}_{2.1}\right)$, faktor individu $\left(\mathrm{X}_{2.2}\right)$, dan faktor psikologis $\left(\mathrm{X}_{2.3}\right)$ terhadap variabel keputusan pembelian $(\mathrm{Y})$ dengan tingkat batas kesalahan 5\%.

e. Pengujian Hipotesis Parsial

Hasil pengujian parsial pada variabel marketing mix yaitu atribut produk $\left(\mathrm{X}_{1.1}\right)$, harga $\left(\mathrm{X}_{1.2}\right)$, saluran distribusi $\left(\mathrm{X}_{1.3}\right)$, promosi $\left(\mathrm{X}_{1.4}\right)$, orang $\left(\mathrm{X}_{1.5}\right)$, proses $\left(\mathrm{X}_{1.6}\right)$, dan lingkungan fisik $\left(\mathrm{X}_{1.7}\right)$ terhadap variabel keputusan pembelian $(\mathrm{Y})$. Dari tabel tersebut dapat dijelaskan yaitu persamaan regresi yang terbentuk: $\mathrm{Y}=-2,439+0,148 \mathrm{X}_{1.1}+0,165 \mathrm{X}_{1.2}+$

$0,191 X_{1.3}+0,206 X_{1.4}+0,360 X_{1.5}+$

$0,370 \mathrm{X}_{1.6}+0,049 \mathrm{X}_{1.7}+\mathrm{e}$

dimana:

$\mathrm{Y}=$ Keputusan Pembelian Konsumen

$\mathrm{X}_{1.1}=$ Variabel Produk

$\mathrm{X}_{1.2}=$ Variabel Harga

$X_{1.3}=$ Variabel Saluran Distribusi

$\mathrm{X}_{1.4}=$ Variabel Promosi

$\mathrm{X}_{1.5}=$ Variabel Orang

$\mathrm{X}_{1.6}=$ Variabel Proses

$\mathrm{X}_{1.7}=$ Variabel Lingkungan Fisik

$\mathrm{e}=$ Error item (variabel lain yang tidak dijelaskan)

\section{Pengaruh Atribut Produk $\left(\mathbf{X}_{1.1}\right)$ terhadap Keputusan Pembelian (Y)}

Nilai thitung yang didapatkan sebesar 2,051 dan nilai signifikansi sebesar 0,043 . Karena nilai $t_{\text {hitung }}$ lebih besar dari $t_{\text {tabel }}(2,051>1,983)$ atau nilai signifikansi lebih kecil dari alpha 5\% $(0,043<0,050)$, maka hipotesis $\mathrm{H}_{0}$ ditolak dan dapat dikatakan bahwa variabel atribut produk $\left(\mathrm{X}_{1.1}\right)$ berpengaruh secara nyata pada variabel keputusan pembelian $(\mathrm{Y})$ pada taraf signifikansi 5\%.

\section{Pengaruh Harga $\left(\mathbf{X}_{1.2}\right)$ terhadap Keputusan Pembelian (Y)}

Nilai thitung yang didapatkan sebesar 2,167 dan nilai signifikansi sebesar 0,033 karena nilai thitung lebih besar dari tabel $(2,167>1,983)$ atau nilai signifikansi lebih kecil dari alpha 5\% $(0,033<0,050)$, maka hipotesis $\mathrm{H}_{0}$ ditolak dan dapat dikatakan bahwa variabel harga $\left(\mathrm{X}_{1.2}\right)$ berpengaruh secara nyata pada variabel keputusan pembelian $(\mathrm{Y})$ pada taraf signifikansi 5\%.

\section{Pengaruh Saluran Distribusi $\left(\mathrm{X}_{1.3}\right)$ terhadap Keputusan Pembelian (Y)}

Nilai thitung yang didapatkan sebesar 2,080 dan nilai signifikansi sebesar 0,040 . Karena nilai thitung lebih besar dari $t_{\text {tabel }}(2,080>1,983)$ atau nilai signifikansi lebih kecil dari alpha 5\% $(0,040<0,050)$, maka hipotesis $\mathrm{H}_{0}$ ditolak dan dapat dikatakan bahwa variabel saluran distribusi $\left(X_{1.3}\right)$ berpengaruh secara nyata pada variabel keputusan pembelian $(\mathrm{Y})$ pada taraf signifikansi 5\%.

\section{Pengaruh Promosi $\left(\mathbf{X}_{1.4}\right)$ terhadap Keputusan Pembelian (Y)}

Nilai thitung yang didapatkan sebesar 2,054 dan nilai signifikansi sebesar 0,043 . Karena nilai thitung lebih besar dari $t_{\text {tabel }}(2,054>1,983)$ atau nilai signifikansi lebih kecil dari alpha 5\% $(0,043<0,050)$, maka hipotesis $\mathrm{H}_{0}$ ditolak dan dapat dikatakan bahwa variabel promosi $\left(\mathrm{X}_{1.4}\right)$ berpengaruh secara nyata pada variabel keputusan pembelian $(\mathrm{Y})$ pada taraf signifikansi $5 \%$.

\section{Pengaruh Orang $\left(\mathbf{X}_{1.5}\right)$ terhadap Keputusan Pembelian (Y)}

Nilai thitung yang didapatkan sebesar 1,994 dan nilai signifikansi sebesar 0,049 . Karena nilai thitung lebih besar dari $\mathrm{t}_{\text {tabel }}(1,994>1,983)$ atau nilai signifikansi lebih kecil dari alpha 5\% $(0,049<0,050)$, maka hipotesis $\mathrm{H}_{0}$ ditolak dan dapat dikatakan bahwa variabel orang $\left(X_{1.5}\right)$ berpengaruh secara nyata pada variabel Keputusan Pembelian (Y) pada taraf signifikansi 5\%.

\section{Pengaruh Proses $\left(\mathbf{X}_{1.6}\right)$ terhadap Keputusan Pembelian (Y)}

Nilai thitung yang didapatkan sebesar 1,994 dan nilai signifikansi sebesar 0,049 . Karena nilai thitung lebih besar dari tabel $(1,994>1,983)$ atau nilai signifikansi lebih kecil dari alpha 5\% $(0,049<0,050)$, maka hipotesis $\mathrm{H}_{0}$ ditolak dan dapat dikatakan bahwa variabel proses $\left(X_{1.6}\right)$ berpengaruh secara nyata pada variabel keputusan pembelian $(\mathrm{Y})$ pada taraf signifikansi $5 \%$. 


\section{Pengaruh Lingkungan Fisik $\left(\mathrm{X}_{1.7}\right)$ terhadap Keputusan Pembelian (Y)}

Nilai $t_{\text {hitung }}$ yang didapatkan sebesar 0,320 dan nilai signifikansi sebesar 0,750 . Karena nilai thitung lebih kecil dari tabel $(0,320<1,983)$ atau nilai signifikansi lebih besar dari alpha $5 \%(0,320>0,050)$, maka hipotesis $\mathrm{H}_{0}$ diterima dan dapat dikatakan bahwa variabel lingkungan fisik $\left(\mathrm{X}_{1.7}\right)$ tidak berpengaruh secara nyata pada variabel keputusan pembelian (Y) pada taraf signifikansi $5 \%$.

Hasil pengujian parsial pada perilaku konsumen yaitu variabel Faktor Lingkungan $\left(\mathrm{X}_{2.1}\right)$, Faktor Individu $\left(\mathrm{X}_{2.2}\right)$, dan Faktor Psikologis $\left(\mathrm{X}_{2.3}\right)$ terhadap variabel Keputusan Pembelian (Y). Dari tabel tersebut dapat dijelaskan yaitu persamaan Regresi yang terbentuk:

$\mathrm{Y}=0,418+0,216 \mathrm{X}_{2.1}+0,235 \mathrm{X}_{2.2}+0,625 \mathrm{X}_{2.3}+\mathrm{e}$ dimana:

$\mathrm{Y}=$ Keputusan Pembelian Konsumen

$\mathrm{X}_{2.1}=$ Faktor Lingkungan

$\mathrm{X}_{2.2}=$ Faktor Individu

$\mathrm{X}_{2.3}=$ Faktor Psikologi

$\mathrm{e}=$ Error item (variabel lain yang tidak dijelaskan)

\section{Pengaruh Faktor Lingkungan $\left(\mathrm{X}_{2.1}\right)$ terhadap Keputusan Pembelian (Y)}

Nilai $t_{\text {hitung }}$ yang didapatkan sebesar 2,714 dan nilai signifikansi sebesar 0,008 . Karena nilai thitung lebih besar dari $t_{\text {tabel }}(2,714>1,983)$ atau nilai signifikansi lebih kecil dari alpha $5 \%(0,008<0,050)$, maka hipotesis $\mathrm{H}_{0}$ ditolak dan dapat dikatakan bahwa variabel faktor lingkungan $\left(\mathrm{X}_{2.1}\right)$ berpengaruh secara nyata pada variabel keputusan pembelian $(\mathrm{Y})$ pada taraf signifikansi $5 \%$.

\section{Pengaruh Faktor Individu $\left(\mathrm{X}_{2.2}\right)$ terhadap Keputusan Pembelian (Y)}

Nilai t hitung yang didapatkan sebesar 2,398 dan nilai signifikansi sebesar 0,018 . Karena nilai t hitung lebih besar dari $t$ tabel $(2,398>1,983)$ atau nilai signifikansi lebih kecil dari alpha $5 \%(0,018<0,050)$, maka hipotesis $\mathrm{H}_{0}$ ditolak dan dapat dikatakan bahwa variabel faktor individu $\left(\mathrm{X}_{2.2}\right)$ berpengaruh secara nyata pada variabel keputusan pembelian $(\mathrm{Y})$ pada taraf signifikansi $5 \%$.

\section{Pengaruh Faktor Psikologis $\left(\mathbf{X}_{2.3}\right)$ terhadap Keputusan Pembelian (Y)}

Nilai thitung yang didapatkan sebesar 5,138 dan nilai signifikansi sebesar 0,000 . Karena nilai thitung lebih besar dari $t_{\text {tabel }}(5,138>1,983)$ atau nilai signifikansi lebih kecil dari alpha 5\% $(0,000<0,050)$, maka hipotesis $\mathrm{H}_{0}$ ditolak dan dapat dikatakan bahwa variabel faktor psikologis $\left(\mathrm{X}_{2.3}\right)$ berpengaruh secara nyata pada variabel keputusan pembelian $(\mathrm{Y})$ pada taraf signifikansi $5 \%$.

\section{KESIMPULAN DAN SARAN}

\section{Kesimpulan}

Berdasarkan hasil penelitian, dapat ditarik kesimpulan sebagai berikut:

1. Variabel dalam marketing mix (atribut produk $\left(\mathrm{X}_{1.1}\right)$, harga $\left(\mathrm{X}_{1.2}\right)$, saluran distribusi $\left(\mathrm{X}_{1.3}\right)$, promosi $\left(\mathrm{X}_{1.4}\right)$, orang $\left(\mathrm{X}_{1.5}\right)$, proses $\left(\mathrm{X}_{1.6}\right)$, lingkungan fisik $\left(\mathrm{X}_{1.7}\right)$ ) secara simultan berpengaruh terhadap keputusan pembelian $H F B$ dan variabel dalam perilaku konsumen (faktor lingkungan $\left(\mathrm{X}_{2.1}\right)$, individu $\left(\mathrm{X}_{2.2}\right)$, psikologis $\left(\mathrm{X}_{2.3}\right)$ ) secara simultan berpengaruh terhadap keputusan pembelian $H F B$.

2. Variabel dalam marketing mix (atribut produk $\left(\mathrm{X}_{1.1}\right)$, harga $\left(\mathrm{X}_{1.2}\right)$, saluran distribusi $\left(\mathrm{X}_{1.3}\right)$, promosi $\left(\mathrm{X}_{1.4}\right)$, orang $\left(\mathrm{X}_{1.5}\right)$, proses $\left.\left(\mathrm{X}_{1.6}\right)\right)$ secara parsial berpengaruh signifikan sedangkan variabel lingkungan fisik $\left(\mathrm{X}_{1.7}\right)$ tidak berpengaruh signifikan terhadap keputusan pembelian $H F B$ dan variabel dalam perilaku konsumen yang (faktor lingkungan $\left(\mathrm{X}_{2.1}\right)$, individu $\left(\mathrm{X}_{2.2}\right)$, psikologis $\left(\mathrm{X}_{2.3}\right)$ ) secara parsial berpengaruh signifikan terhadap keputusan pembelian $H F B$.

\section{Saran}

1. Produsen produk $H F B$ dapat mempertahankan kualitas produk bahkan inovasi terhadap variasi produk seiring dengan tingkat keputusan pembelian konsumen yang tinggi terhadap produk $H F B$ di Malang.

2. Berdasarkan hasil penelitian, produsen dapat meningkatkan seluruh aspek-aspek secara bertahap, atau mencari salah satu variabel yang paling berpengaruh terhadap kepuasan pelanggannya yang juga bisa dipakai oleh peneliti berikutnya (future researcher).

\section{DAFTAR PUSTAKA}

Badan Pusat Statistik. 2013. Penduduk Berumur 15 Tahun Ke Atas Menurut Jenis Kegiatan. http://www.bps.go.id. Tanggal akses 5 Mei 2013

Datrex. 2009. Food Bars VS Canned Goods. http://www.survivalinstinct.com/maydayfood bars.html. Tanggal akses 4 Mei 2013. 
Engel, J.F., Roger D.B., and Paul W.M. 1994. Consumer Behavior, Fifth Edition, The Dreyden Press, New York.

Ghozali, I. 2006, Aplikasi Analisis Multivariate. Universitas Diponegoro. Semarang.

Haryadi, R. 2009. Pengaruh Strategi Green Marketing Terhadap Pilihan Konsumen Melalui Pendekatan Marketing Mix (Studi Kasus Pada The Body Shop Jakarta): Green Commodity. Journal of Macromarketing, Vol 20 No.1, 51.

Kotler, P., 1997. Manajemen Pemasaran. Jilid II. Prendallindo, Jakarta.

Leach, R. 1995. Nutrient Fortified Food Bar. Journal United States Patent Publications. No: 548,804.

Lovelock, C.H., and L.K. Wright. 1999. Principles of Service Marketing and Management, PrenticeHall Inc., New Jersey.

Lumiar, G. 2010. Analisis Sifat Fisik Dan Ekonomi Makanan Padat (Food Bars) Berbasis Tepung Komoditas Lokal. Skripsi. Universitas Brawijaya. Malang.

Manongko, A. 2011. Green Marketing Dan Pengaruhnya Terhadap Keputusan Pembelian Melalui
Minat Membeli Produk Organik. Skripsi. Universitas Brawijaya. Malang.

McDaniel, Lamb and Hair. 2012. Marketing Essentials. Cengange Learning. Canada.

Peter, J.P dan Jerry C.O. 2000. Consumer behavior: Perilaku Konsumen Dan Strategi Pemasaran Edisi Keempat. Erlangga. Jakarta.

Savige G, Farlane A.M, Ball K, Worsley A, and Kwarford D. 2007. Snacking behaviours of adolescents and their association with skipping meals. International Journal of Behavioral Nutrition and Physical Activity. Vol. 4 No. 36, 12-17. http://www.ijbnpa.org/content/4/1/36. Tanggal akses 4 Mei 2013.

Schiffman, L.G., and Kanuk, L.L. 2004. Consumer Behaviour. Prentice Hall. New Jersey

Singarimbun dan Sofian E. 2006. Metode Penelitian Survei. Salemba Empat. Jakarta.

Sugiyono. 2003. Statistika Untuk Penelitian. CV Alfabeta. Bandung.

The Chartered Institute of Marketing. 2009. The 7Ps of Marketing. CIM Insights. Berkshire England. 